\title{
Effects of fertilization regimes on tea yields, soil fertility, and soil microbial diversity
}

\author{
Shan-Lian Qiuํ, Li-Min Wang¹, Dong-Feng Huang ${ }^{1}$, and Xin-Jian Lin ${ }^{1 *}$
}

Fertilization is an important agricultural practice for increasing crop yields and influencing soil properties. A field experiment was conducted in the period of 2006-2011 in southeastern China, to investigate the effects of fertilization regimes on tea (Camellia sinensis [L.] Kuntze) yields, soil chemical properties, and soil bacterial and fungal communities. The field experiment included six treatments: (1) unfertilized control (CON); (2) chemical fertilizers (NPK); (3) half-chemical fertilizers plus half-organic manure (1/2NPKOM); (4) organic manure fertilizers (OM); (5) half-chemical fertilizers plus half-organic manure plus legume stover returned $(1 / 2 \mathrm{NPKOM}+\mathrm{L})$, and $(6)$ chemical fertilizers plus legume stover returned (NPKL). Results showed that, compared to the control, NPK treatment showed no significant effect on soil organic matter (SOM), total N (TN), total P (TP), total K (TK), available N (AN), available K (AK) and tea yields, but showed the lowest bacterial Shannon index of 1.714 and the lowest value of 2.002 for fungal Shannon index. Organic manure treatment had the richest diversity of soil bacterial community with Shannon index of 2.542, and the highest levels of soil essential nutrients, including SOM (30.03\%), TN (2.90 $\left.\mathrm{g} \mathrm{kg}^{-1}\right)$, TP (1.35 $\left.\mathrm{g} \mathrm{kg}^{-1}\right), \mathrm{AN}\left(245.30 \mathrm{mg} \mathrm{kg}^{-1}\right)$, AP (57.00 mg kg-1), and AK (271.80 mg $\mathrm{kg}^{-1}$ ), followed by $1 / 2 \mathrm{NPKOM}+\mathrm{L}$, which appeared the maximal tea yields of $6772 \mathrm{~kg} \mathrm{ha}^{-1}$. Organic manure amendment was a key factor in determining soil properties and productivity. Base on soil quality and tea yields, both OM and 1/2NPKOM+L treatments were recommended as better choices of fertilization practices for tea soils in southeastern China. These findings provided a better understanding of the importance of fertilizations in promoting soil fertility, crop yields, and altering soil microbial diversity, leading to selection of scientific fertilization practices for sustainable development of agroecosystems.

Key words: Camellia sinensis, fertilization, soil chemical properties, soil microbial diversity, tea yields.

\section{INTRODUCTION}

Tea (Camellia sinensis [L.] Kuntze) is widely planted in China, covering 20 provinces from Hainan Province in the south to Shandong in the north, from Tibet in the west to Taiwan in the east. Fertilization, as an important agricultural practice, not only can increase crop yields and maintain soil fertility, but also result in shifts in the microbial communities, which play a critical role in maintaining the agroecosystem health through soil formation and biochemical processes, including residue decomposition and nutrient cycling. Many studies have focused on fertilization regimes on soil fertility (Yang et al., 2007; Liu et al., 2010), crop yields (Venkatesan et al., 2004; Zhu et al., 2007) and microbial communities (He et al., 2008; Shen et al., 2010), but, up to now, the results of these reports are still not unanimous, and even conflicted. Moreover, most studies were concerned about the soils for growing food crops, like rice (Wu et al., 2011), wheat (Shen et al., 2010), maize or their combination

${ }^{1}$ Soil and Fertilizer Institute, Fujian Academy of Agricultural Sciences, Fuzhou, Fujian 350003, China.

"Corresponding author (xinjianlin@163.net).

Received: 26 October 2013.

Accepted: 9 June 2014.

doi:10.4067/S0718-58392014000300012 for rotation (Kumar and Yadav, 2001; Yang et al., 2007; $\mathrm{Hu}$ et al., 2011), while few about the soils for planting tea (Venkatesan et al., 2004). Hence, it is necessary to examine the effects of fertilization regimes on tea yields, soil fertility, and microbial communities. Particularly, soil microorganisms which are essential for maintaining the sustainability and productivity of terrestrial ecosystems (Naeem and Li, 1997; Costa et al., 2007), usually respond more rapidly to changing soil conditions than do either chemical or physical properties (Šimek et al., 1999), and have been considered to be one of the most sensitive biological indicators for measuring soil quality (Kennedy, 1999). Therefore, studying the shifts of microbial communities under different fertilizations can help us to better understand the impact of fertilizers on soil quality. In this study, we took advantage of culture-independent methods including PCR and temperature gradient gel electrophoresis (TGGE) to detect the microbial diversity in a tea soil under different fertilization practices.

Knowledge about the shifts of soil fertility, crop yields, and microbial communities following different fertilizer management practices can improve our understanding of soil processes and thus help us to develop better management strategies which can maintain or improve soil fertility, increase tea yields and minimize damages to the agroecosystem. This study aimed to determine the 
effects of annual applications of inorganic and organic fertilizers on soil chemical properties, tea yields, and soil bacterial and fungal diversity in a tea soil in southeastern China.

\section{MATERIALS AND METHODS}

\section{Site description, treatment, and soil sampling}

A field trial was established in 2006 to determine the effects of different fertilizations on soil fertility, tea yields, and microbial communities. The study site is located at the Fu'an Experimental Station (26 $41^{\circ}$ '-27 $24^{\circ}$ N, $119^{\circ} 23^{\prime}-119^{\circ} 51^{\prime}$ E) of Fujian Academy of Agricultural Sciences (FAAS), Fujian Province, southeastern China. This region has a subtropical marine monsoon climate with a mean annual precipitation of $1540 \mathrm{~mm}$, temperature of $19.3{ }^{\circ} \mathrm{C}$ and sunshine of $1837 \mathrm{~h}$. The tea cultivar was 'Huangguanyin'. Six fertilization treatments with triplicate for each treatment were designed as follows: (1) unfertilized control (CON), (2) chemical fertilizers (NPK), (3) half-organic manure plus half-chemical fertilizers (1/2NPKOM), (4) organic manure fertilizers (OM), (5) half-organic manure plus legume stover returned plus half-chemical fertilizers (1/2NPKOM+L), and (6) legume stover returned plus chemical fertilizers (NPKL) (Table 1). Treatments were allocated in the randomized complete block design. Band fertilization was carried out every winter. For NPK-containing treatments, N, P, K was applied in the form of urea, monoammonium phosphate, and potassium chloride, respectively. Organic manure fertilizers was the industrial farmyard manure made chiefly of chicken manure, with organic matter content of $368.90 \mathrm{~g} \mathrm{~kg}^{-1}$, total $\mathrm{N}$ (TN) $9.00 \mathrm{~g} \mathrm{~kg}^{-1}$, total P (TP) 22.90 $\mathrm{g} \mathrm{kg}^{-1}$, total K (TK) $5.29 \mathrm{~g} \mathrm{~kg}^{-1}$. The legume plant (Cassia rotundifolia Pers.), using a seed rate of $7.5 \mathrm{~kg} \mathrm{ha}^{-1}$, was drilled into the top soil of spaces between tea tree rows. After the plant fades every winter, their mature seeds fell along the rows and naturally sprout in the next spring. Soil composite samples $(0-20 \mathrm{~cm})$ from each plot (size of $13.65 \mathrm{~m}^{2}$ ) were taken randomly in May 2011. The soil was sieved $(<2 \mathrm{~mm})$ and stored at $-20^{\circ} \mathrm{C}$ for DNA extraction and $4{ }^{\circ} \mathrm{C}$ for other analyses.

\section{Soil analysis}

Soil $\mathrm{pH}$ was measured with a $\mathrm{pH}$ meter (EL20K, MettlerToledo, Columbus, Ohio, USA) using soil:water of 1:2.5 suspensions (Thomas, 1996). Soil organic matter
(SOM) was determined by $\mathrm{K}_{2} \mathrm{Cr}_{2} \mathrm{O}_{7}$ oxidation-reduction titration method (Walkley and Black, 1934). Soil TN was measured using the Kjeldahl digestion-distillation method (Bremner, 1960). The TP was determined colorimetrically according to the molybdenum blue method, following persulfate digestion (Murphy and Riley, 1962). Soil TK was digested by $\mathrm{HF}^{-} \mathrm{HClO}_{4}$ (Jackson, 1958) and determined by flame photometry. Available N (AN) and available $\mathrm{P}$ (AP) were determined by $\mathrm{NaOH}$ hydrolysable and molybdenum methods, respectively. Available $\mathrm{K}$ (AK) was extracted by ammonium acetate and determined by flame photometry (Carson, 1980). In this study, tea yields represented the cumulative tea production obtained between 2008 and 2011.

Soil DNA was extracted using a FastDNA SPIN Kit for soil (MP Biomedicals, Solon, Ohio, USA) according to the instructions of manufacturer. For soil bacteria, the $16 \mathrm{~S}$ rDNA V3 fragments were amplified using the fD1/rD1 (Weisburg et al., 1991) and F341GC/R534 (Muyzer et al., 1993) primers with nested PCR. Amplification using primer pair $\mathrm{fD} 1 / \mathrm{rD} 1$ was performed in $50-\mu \mathrm{L}$ reaction mixtures, including $5 \mu \mathrm{L} 10 \times \mathrm{PCR}$ buffer with $\left(\mathrm{NH}_{4}\right)_{2} \mathrm{SO}_{4}$, $3 \mu \mathrm{L} 25 \mathrm{mM} \mathrm{MgCl}_{2}, 4 \mu \mathrm{L} 2.5 \mathrm{mM}$ dNTPs, $0.5 \mu \mathrm{L} 5 \mathrm{U}$ $\mu \mathrm{L}^{-1}$ Taq DNA polymerase (MBI Fermentas, Burlington, Ontario, Canada), $1 \mu \mathrm{L} 20 \mu \mathrm{M}$ each primer, and $1 \mu \mathrm{L}$ DNA template (10-50 ng). A touchdown PCR strategy was employed as follows: $5 \mathrm{~min}$ at $94^{\circ} \mathrm{C}, 20$ cycles of $1 \mathrm{~min}$ at $94{ }^{\circ} \mathrm{C}, 45 \mathrm{~s}$ at temperatures decreasing from 65 to $55^{\circ} \mathrm{C}, 2$ min at $72^{\circ} \mathrm{C}, 10$ cycles of $1 \mathrm{~min}$ at $94^{\circ} \mathrm{C}, 45 \mathrm{~s}$ at $55^{\circ} \mathrm{C}, 2$ min at $72{ }^{\circ} \mathrm{C}$, and final extension for $5 \mathrm{~min}$ at $72^{\circ} \mathrm{C}$. PCR amplification of a $16 \mathrm{~S}$ rDNA V3 fragment using primer pair F341GC/R534 was carried out in a $25 \mu \mathrm{L}$ containing $2.5 \mu \mathrm{L}$ PCR buffer, $1.5 \mu \mathrm{L} \mathrm{MgCl}_{2}, 2.8 \mu \mathrm{L}$ dNTPs, $0.5 \mu \mathrm{L}$ Taq DNA polymerase, $0.5 \mu \mathrm{L}$ each primer, and $1 \mu \mathrm{L}$ DNA template (Amplicons resulted from fD1/rD1 were diluted 1:100). Concentrations of PCR components and cycling conditions were the same as above. For fungi, fragments of 18S rDNA gene were amplified with primer pair FR1GC/FF390 as described by Vainio and Hantula (2000). All PCR components $(50 \mu \mathrm{L})$ were the same as fD1/rD1 reactions except for PCR buffer $(10 \times$ buffer with $\mathrm{KCl})$ and primer pair. The PCR procedure was as follows: $3 \mathrm{~min}$ at $95{ }^{\circ} \mathrm{C}$, then 35 cycles of $30 \mathrm{~s}$ at $95{ }^{\circ} \mathrm{C}, 45 \mathrm{~s}$ at $50{ }^{\circ} \mathrm{C}$, $1 \mathrm{~min}$ at $72{ }^{\circ} \mathrm{C}$, and final extension for $10 \mathrm{~min}$ at $72{ }^{\circ} \mathrm{C}$ (Beauregard et al., 2010). All reactions were carried out using a Whatman Biometra T1 96-well Thermocycler. Primer sequences are listed in Table 2.

Table 1. Fertilization treatments at the Fu'an experimental station.

\begin{tabular}{|c|c|c|c|c|}
\hline \multirow[b]{2}{*}{ Treatments } & \multicolumn{3}{|c|}{ Chemical fertilizer } & \multirow[b]{2}{*}{ Organic amendment } \\
\hline & $\mathrm{N}$ & $\mathrm{P}$ & $\overline{\mathrm{K}}$ & \\
\hline & \multicolumn{3}{|c|}{$\mathrm{kg} \mathrm{ha}^{-1}$} & \\
\hline Control (CON) & 0 & 0 & 0 & 0 \\
\hline NPK & 208 & 68 & 56 & 0 \\
\hline $1 / 2 \mathrm{NPK}+1 / 2$ organic manure $(1 / 2 \mathrm{NPKOM})$ & 104 & 34 & 28 & $5.7 \mathrm{t} \mathrm{ha}^{-1}$ organic manure \\
\hline Organic manure $(\mathrm{OM})$ & 0 & 0 & 0 & $11.4 \mathrm{t} \mathrm{ha}^{-1}$ organic manure \\
\hline $1 / 2 \mathrm{NPK}+1 / 2$ organic manure + leguminous stover returned $(1 / 2 \mathrm{NPKOM}+\mathrm{L})$ & 104 & 34 & 28 & $5.7 \mathrm{t} \mathrm{ha}^{-1}$ organic manure plus legume stover returned \\
\hline NPK + leguminous stover returned (NPKL) & 208 & 68 & 56 & Legume stover returned \\
\hline
\end{tabular}


Table 2. Primers used in this study.

\begin{tabular}{|c|c|c|c|}
\hline $\begin{array}{l}\text { Target } \\
\text { group }\end{array}$ & Primer & Sequence $\left(5^{\prime} \rightarrow 3^{\prime}\right)$ & $\begin{array}{l}\text { Length of } \\
\text { amplicon } \\
\text { (bp) }\end{array}$ \\
\hline \multirow[t]{4}{*}{ Bacteria } & fD1 & GAGTTTGATCCTGGCTCA G & \multirow[t]{2}{*}{1533} \\
\hline & rD1 & AGA AAGGAGGTGATCCAGCC & \\
\hline & F341GC & GC clampa-CCTACGGGAGGCAGCAG & \multirow[t]{2}{*}{234} \\
\hline & R534 & ATTACCGCGGCTGCTGG & \\
\hline \multirow[t]{2}{*}{ Fungi } & FR1-GC & GC clamp $^{\text {b-AICCATTCAATCGGTAIT }}$ & \multirow[t]{2}{*}{430} \\
\hline & FF390 & CGATAACGAACGAGACCT & \\
\hline
\end{tabular}

GC clamp ${ }^{\mathrm{a}}$ represents CGC CCG CCG CGC GCG GCG GGC GGG GCG GGG GCA CGG GGG G.

GC clamp ${ }^{b}$ represents CCC CCG CCG CGC GCG GCG GGC GGG GCG GGG GCA CGG GCC G.

PCR products were loaded on $0.45-\mathrm{mm}$ thick $8 \%$ denaturing gels $(8 \%$ polyacrylamide gel $[\mathrm{Acr} / \mathrm{Bis}=37.5: 1]$, $1 \times$ TAE [40 mM Tris-Cl, 1 mM EDTA], 2\% glycerol, and $8 \mathrm{M}$ urea). Temperature gradient gel electrophoresis (TGGE) was performed using a TGGE system (Whatman Biometra, Goettingen, Germany). All gels were run at $130 \mathrm{~V}$ for $3 \mathrm{~h}$ with $1 \times \mathrm{TAE}$ buffer. Temperature gradient was optimized at $56-69{ }^{\circ} \mathrm{C}$ for bacteria and $49-61{ }^{\circ} \mathrm{C}$ for fungi. After electrophoresis, gels were silver-stained using the procedures devised by Bassam and CaetanoAnollés (1993). Gel images were captured using the Cannon camera and analyzed by the Bio-rad Quantity One software. The diversity indices (Shannon index) were calculated according to TGGE patterns. Each resolved band was considered as a specific phylotype. The pixel intensity of each band detected by Quantity One software represented the abundance of a specific phylotype for diversity estimations. The Shannon-Weaver indices $\left(H^{\prime}\right)$ (Shannon and Weaver, 1963) were calculated using the following Equation [1]:

$$
H^{\prime}=-\sum p_{i} \ln p_{i}
$$

where $p_{i}=n_{i} / \sum n, n_{i}$ is the abundance of the $i^{\text {th }}$ phylotype per lane, and $\Sigma n$ is the total abundance of all phylotypes per lane.

Finally, cluster analysis according to the TGGE patterns was employed to produce the dendrograms by the unweighted pair-group method with arithmetic average (UPGMA) method using Quantity One software.

\section{Statistical analysis}

One-way ANOVA was employed to analyze differences of all soil indices. Post hoc tests for each variable were made using LSD comparisons. Significant differences for all statistical tests were evaluated at the level of $P<0.05$. The Pearson correlation analysis was utilized to determine the correlations between all the measured parameters. All data analyses were conducted with the SPSS software (SPSS for Windows, Version 18.0, Chicago, Illinois, USA).

\section{RESULTS AND DISCUSSION}

\section{Effect of different fertilizations on soil chemical properties and tea yields}

Soil pH and nutrient contents are summarized in Table 3. Soil $\mathrm{pH}$ ranging from 5.40 to 5.68 was not significantly different across all treatments, indicating that there was no noticeable effect of fertilizers on soil $\mathrm{pH}$ after $5 \mathrm{yr}$ of continuous annual fertilizer applications. Yang et al. (2007) and $\mathrm{Gu}$ et al. (2009) also reported that inorganic fertilizer and organic amendment had no effect on soil $\mathrm{pH}$ after $22 \mathrm{yr}$ of continuous annual fertilizer applications. However, Shen et al. (2010) and Hu et al. (2011) showed that inorganic and organic fertilization significantly decreased soil $\mathrm{pH}$ after long-term fertilizer applications. These inconsistent results could be due to different soil types, its properties, climate, duration of the experiment, etc.

Table 3a. Effects of different fertilization treatments on soil chemical properties and tea yields.

\begin{tabular}{|c|c|c|c|c|c|}
\hline Treatments & $\mathrm{pH}$ & SOM & TN & $\mathrm{TP}$ & TK \\
\hline & & $-\%-$ & - & $-\mathrm{g} \mathrm{kg}^{-1}$ & 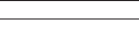 \\
\hline $\mathrm{CON}$ & $5.64 \pm 0.32 a$ & $9.16 \pm 2.50 \mathrm{~d}$ & $0.63 \pm 0.19 \mathrm{c}$ & $0.20 \pm 0.05 \mathrm{~d}$ & $18.13 \pm 1.81 \mathrm{a}$ \\
\hline NPK & $5.40 \pm 0.26 a$ & $9.00 \pm 1.57 \mathrm{~d}$ & $0.72 \pm 0.20 \mathrm{c}$ & $0.34 \pm 0.01 \mathrm{~cd}$ & $21.84 \pm 5.60 \mathrm{a}$ \\
\hline 1/2NPKOM & $5.47 \pm 0.07 a$ & $17.33 \pm 6.15 b c$ & $1.41 \pm 0.82 b c$ & $0.62 \pm 0.38 b c$ & $18.90 \pm 6.32 a$ \\
\hline $\mathrm{OM}$ & $5.67 \pm 0.20 a$ & $30.03 \pm 5.86 \mathrm{a}$ & $2.90 \pm 0.81 \mathrm{a}$ & $1.35 \pm 0.12 \mathrm{a}$ & $18.22 \pm 3.07 \mathrm{a}$ \\
\hline $1 / 2 \mathrm{NPKOM}+\mathrm{L}$ & $5.42 \pm 0.17 a$ & $21.00 \pm 1.65 b$ & $1.71 \pm 0.14 b$ & $0.81 \pm 0.14 b$ & $21.03 \pm 4.23 \mathrm{a}$ \\
\hline NPKL & $5.68 \pm 0.14 a$ & $12.60 \pm 0.87 \mathrm{~cd}$ & $0.88 \pm 0.10 b c$ & $0.32 \pm 0.06 \mathrm{~cd}$ & $16.27 \pm 3.54 \mathrm{a}$ \\
\hline
\end{tabular}

CON: unfertilized control; NPK: chemical fertilizers; 1/2NPKOM: half-chemical fertilizers plus half-organic manure; OM: organic manure fertilizers; 1/2NPKOM+L: half-chemical fertilizers plus half-organic manure plus legume stover returned; NPKL: chemical fertilizers plus legume stover returned; SOM: soil organic matter; TN: total N; TP: total P; TK: total K.

Table 3b. Effects of different fertilization treatments on soil chemical properties and tea yields.

\begin{tabular}{|c|c|c|c|c|}
\hline Treatments & $\mathrm{AN}$ & $\mathrm{AP}$ & $\mathrm{AK}$ & Tea yield \\
\hline & 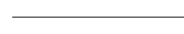 & $\mathrm{mg} \mathrm{kg}^{-1}$ & - & $-\mathrm{kg} \mathrm{ha}^{-1}-$ \\
\hline $\mathrm{CON}$ & $89.13 \pm 17.70 \mathrm{c}$ & $1.34 \pm 0.28 \mathrm{c}$ & $58.17 \pm 7.74 \mathrm{~d}$ & $2309 \pm 122 c$ \\
\hline NPK & $131.57 \pm 40.12 b c$ & $16.97 \pm 0.42 b$ & $100.67 \pm 8.88 \mathrm{~cd}$ & $3696 \pm 677 b c$ \\
\hline 1/2NPKOM & $164.77 \pm 62.22 b$ & $23.03 \pm 10.60 \mathrm{~b}$ & $180.10 \pm 28.50 b$ & $5220 \pm 773 \mathrm{ab}$ \\
\hline $\mathrm{OM}$ & $245.30 \pm 30.82 \mathrm{a}$ & $57.00 \pm 5.89 a$ & $271.80 \pm 45.12 \mathrm{a}$ & $5495 \pm 908 \mathrm{ab}$ \\
\hline 1/2NPKOM+L & $231.20 \pm 18.58 \mathrm{a}$ & $47.37 \pm 3.26 a$ & $252.83 \pm 19.66 \mathrm{a}$ & $6772 \pm 1095 a$ \\
\hline NPKL & $137.70 \pm 23.38 b c$ & $14.77 \pm 6.07 b$ & $108.50 \pm 35.26 c$ & $5102 \pm 1236 b$ \\
\hline
\end{tabular}

Values are given as means \pm SD $(n=3)$; Values within a column followed by different lowercase letters are significantly different $(\mathrm{n}=3$, LSD, $\mathrm{P}<0.05)$. CON: unfertilized control; NPK: chemical fertilizers; 1/2NPKOM: half-chemical fertilizers plus half-organic manure; OM: organic manure fertilizers; 1/2NPKOM+L: half-chemical fertilizers plus half-organic manure plus legume stover returned; NPKL: chemical fertilizers plus legume stover returned; SOM: soil organic matter; TN: total N; TP: total P; TK: total K; AN: available N; AP: available P; AK: available K. 
Different fertilizer applications caused significant changes in soil chemical properties (Table 3). SOM contents varied from $9.00 \%$ to $30.03 \%$, and the highest value occurred in OM treatment and the lowest in NPK treatment. Furthermore, SOM contents in the treatments (OM, 1/2NPKOM, and 1/2NPKOM+L) with organic manure were significantly $(P<0.05)$ higher than that in the unfertilized control (CON) and NPK treatment. Similarly, the contents of TN, TP, AN, AP, and AK were the highest in $\mathrm{OM}$ treatment, the second highest in $1 / 2 \mathrm{NPKOM}+\mathrm{L}$ treatment but the lowest in CON treatment. Obviously, the OM-containing treatments $(\mathrm{OM}, 1 / 2 \mathrm{NPKOM}$, and $1 / 2 \mathrm{NPKOM}+\mathrm{L}$ ) showed much greater increase in soil chemical fertility, which could be attributed to the regular and greater addition of organic manure for $5 \mathrm{yr}$. However, application of inorganic fertilizer alone (NPK) showed no significant effect on soil chemical properties (except for AP) compared to CON treatment, this was consistent with the findings at Xinhua and Ningxiang in Hunan, China (Hao et al., 2008).

The cumulative yield data of tea obtained from 2008 to 2011 were analyzed statistically and also shown in Table 3 , ranging from 2309 to $6772 \mathrm{~kg} \mathrm{ha}^{-1}$. In comparison with CON treatment, the four organic-containing treatments (i.e., $1 / 2 \mathrm{NPKOM}, \mathrm{OM}, 1 / 2 \mathrm{NPKOM}+\mathrm{L}$, and NPKL) significantly $(P<0.05)$ increased tea production. The maximum tea yields were observed in the $1 / 2 \mathrm{NPKOM}+\mathrm{L}$ treatment and nearly twice higher than that in CON treatment. Among all the treatments, the tea productions were ranked as follows: $1 / 2 \mathrm{NPKOM}+\mathrm{L}>\mathrm{OM}>$ $1 / 2 \mathrm{NPKOM}>\mathrm{NPKL}>\mathrm{NPK}>\mathrm{CON}$.

\section{Effect of different fertilizations on soil microbial communities}

The TGGE profiles of the bacterial and fungal communities of the samples are shown in Figures 1a and $1 \mathrm{~b}$, respectively. For both bacteria and fungi, there were obviously fewer bands detected in NPK than in other treatments, suggesting that application of chemical fertilizer alone declined bacterial and fungal richness and diversity. In addition, the bacterial Shannon index in NPK treatment had the lowest value of 1.714, which was in accordance with Kamaa et al. (2011), who showed that the bacterial diversity was negatively affected by inorganic fertilizer alone. In this experiment, the OM treatment had the maximum bacterial diversity, followed by $1 / 2 \mathrm{NPKOM}+\mathrm{L}$ and $1 / 2 \mathrm{NPKOM}$, this confirmed many earlier findings that organic amendments promoted the bacterial diversity (Peacock et al., 2001; Mäeder et al., 2002; Sun et al., 2004; Gu et al., 2009), probably due to input of foreign microorganisms and improvement of soil properties under organic manure application. For fungi, all fertilization treatments appeared a trend towards distinct fungal community structures (Figure 1b), and significantly $(P<0.05)$ lower diversity (Table 4$)$ when compared to $\mathrm{CON}$ treatment. This is in conflict with

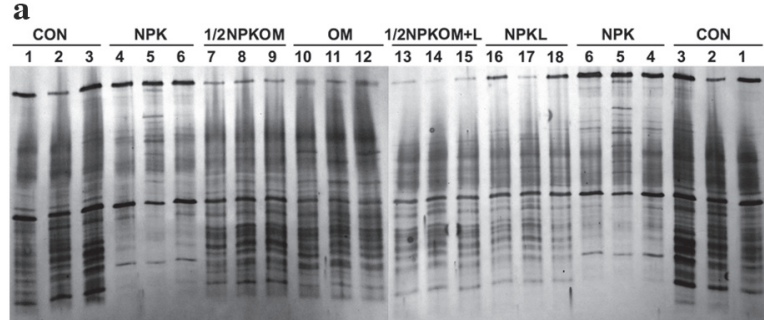

b

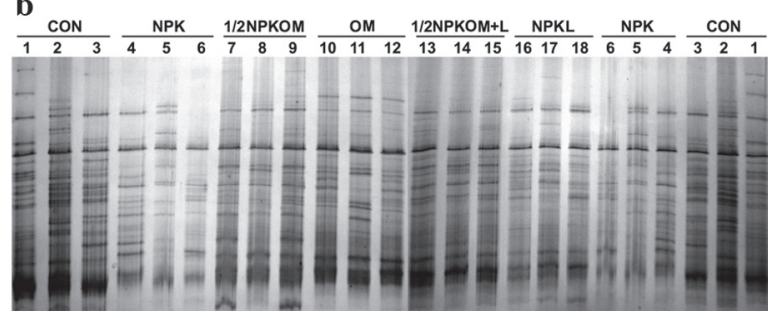

CON: unfertilized control; NPK: chemical fertilizers; 1/2NPKOM: half-chemical fertilizers plus half-organic manure; OM: organic manure fertilizers; $1 / 2 \mathrm{NPKOM}+\mathrm{L}$ : half-chemical fertilizers plus half-organic manure plus legume stover returned; NPKL: chemical fertilizers plus legume stover returned.

Figure 1. Temperature gradient gel electrophoresis (TGGE) profiles of (a) 16S rRNA and (b) 18S rRNA genes of soil samples under different fertilization practices.

Kamaa et al. (2011), who showed that the fungal diversity was the lowest in fallow and control treatments and significantly lower than the other treatments. The reasons for this inconsistent result could be due to different physical texture and (or) chemical nutrient elements and (or) crop cover types in different soil types, which were suggested to be the dominant factors, controlling the general microbial community composition (Larkin et al., 2006).

Cluster analyses (Figure 2a) based on bacterial TGGE profiles showed the three OM-containing (OM, 1/2NPKOM, 1/2NPKOM+L) had a relatively similar banding pattern and clustered together in Cluster 2 . Within Cluster 1, the triplicate within NPK treatment further grouped into a smaller cluster, indicating different bacterial community structures in the NPK soil. Two clusters of bacterial dendrogram clearly distinguished

Table 4. Effects of different fertilization treatments on soil bacterial and fungal diversity.

\begin{tabular}{lcc}
\hline Treatments & $\begin{array}{c}\text { Bacterial Shannon- } \\
\text { Weaver index }\end{array}$ & $\begin{array}{c}\text { Fungal Shannon- } \\
\text { Weaver index }\end{array}$ \\
\hline CON & $2.324 \pm 0.093 \mathrm{a}$ & $2.688 \pm 0.111 \mathrm{a}$ \\
NPK & $1.714 \pm 0.338 \mathrm{~b}$ & $2.002 \pm 0.298 \mathrm{~b}$ \\
$1 / 2 \mathrm{NPKOM}$ & $2.391 \pm 0.176 \mathrm{a}$ & $2.188 \pm 0.303 \mathrm{~b}$ \\
OM & $2.542 \pm 0.176 \mathrm{a}$ & $2.167 \pm 0.131 \mathrm{~b}$ \\
$1 / 2 \mathrm{NPKOM}+\mathrm{L}$ & $2.422 \pm 0.054 \mathrm{a}$ & $2.225 \pm 0.112 \mathrm{~b}$ \\
NPKL & $2.324 \pm 0.158 \mathrm{a}$ & $2.280 \pm 0.137 \mathrm{~b}$ \\
\hline
\end{tabular}

Values are given as means $\pm \mathrm{SD}(\mathrm{n}=3)$.

Values within a column followed by different lower-case letters are significantly different $(\mathrm{n}=3, \mathrm{LSD}, \mathrm{P}<0.05)$.

CON: Unfertilized control; NPK: chemical fertilizers; 1/2NPKOM: halfchemical fertilizers plus half-organic manure; OM: organic manure fertilizers; 1/2NPKOM+L: half-chemical fertilizers plus half-organic manure plus legume stover returned; NPKL: chemical fertilizers plus legume stover returned. 
a

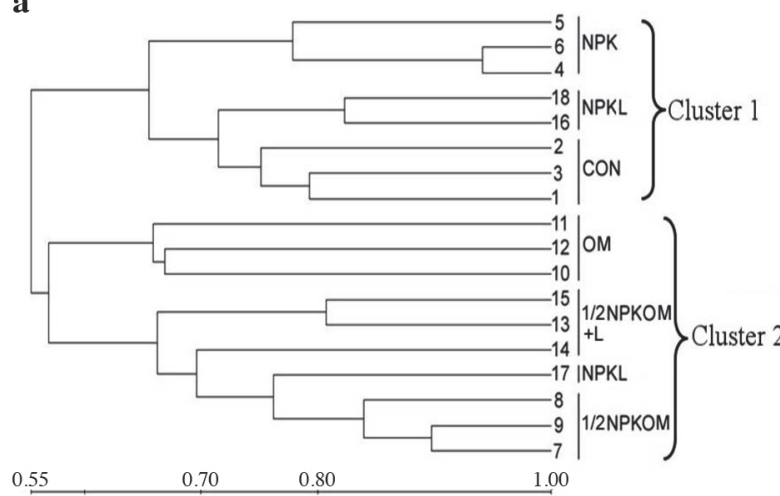

b

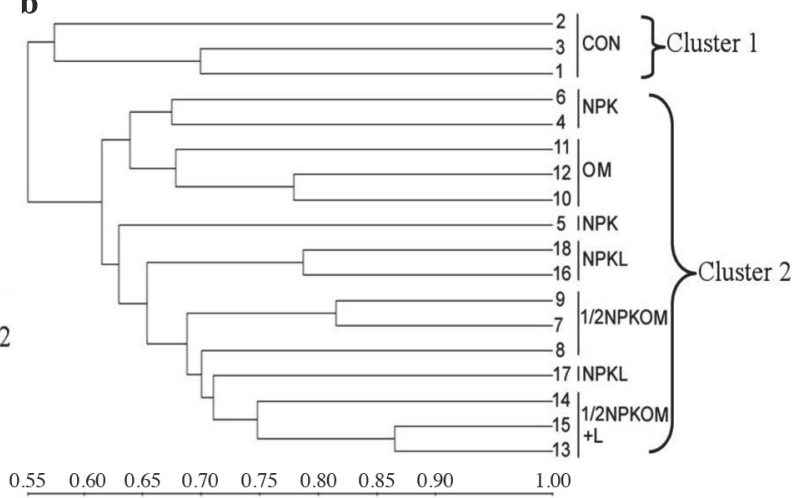

CON: unfertilized control; NPK: chemical fertilizers; 1/2NPKOM: half-chemical fertilizers plus half-organic manure; OM: organic manure fertilizers; 1/2NPKOM+L: half-chemical fertilizers plus half-organic manure plus legume stover returned; NPKL: chemical fertilizers plus legume stover returned.

Figure 2. Cluster analysis of temperature gradient gel electrophoresis (TGGE) fingerprints in Figure 1 (a) 16S rRNA and (b) 18S rRNA genes.

between soils treated with organic manure input and soils without organic manure input, suggesting that applications of organic manure had important effects on soil bacterial communities. For fungal TGGE profiles, cluster analyses showed that the CON treatment was separated at the first branch (Figure 2b) and clearly distinguished itself from the treatments with fertilizer, indicating that the highest difference of fungal community existed between CON and other fertilization treatments, and thus, inorganic, organic inputs and their combination significantly altered soil fungal community structures. The treatments of NPKL, $1 / 2 \mathrm{NPKOM}$, and $1 / 2 \mathrm{NPKOM}+\mathrm{L}$ were more closely combined in one sub-group (Figure $2 b$ ), which indicated that combined use of organic input with inorganic fertilizers lead to more similar fungal communities. Unexpectedly, we observed that within NPKL treatment, Sample 17 could not be closely clustered into a group containing Samples 16 and 18 (Figures 2a and 2b), suggesting that the experimental replication in the same treatment was not good in this field trial, possibly due to spatial variation of hilly area in tea fields.

Relationships among soil properties, tea yields, and microbial diversity indices

Soil $\mathrm{pH}$ is one of the most influential factors affecting the microbial community in soil (Rousk et al., 2009; 2010). In this study, soil $\mathrm{pH}$ was positively correlated with the Shannon indices of bacteria $(\mathrm{r}=0.541, P<0.05$, Table 5). Soil organic matter (SOM), as an important component of the soil, plays a key role in determining soil physical, chemical, and biological properties that strongly affect crop production (Powlson et al., 2012; Peng et al., 2014). Therefore, maintaining and increasing SOM content in agricultural soils is of paramount importance. Usually, balance application of inorganic fertilizers and organic amendments increased organic input to the soil, then enhanced SOM content (Kanchikerimath and Singh, 2001; Hai et al., 2010), improved soil fertility and crop production (Zhu et al., 2007; Liu et al., 2010). In our study, SOM contents were positively correlated with contents of TN (r = 0.987, $P<0.01)$, TP (r $=0.964, P$ $<0.01)$, AN (r = 0.914, $P<0.01)$, AP (r = 0.867, $P<$ $0.01)$, and AK $(\mathrm{r}=0.904, P<0.01)$, and with tea yields ( $\mathrm{r}=0.589, P<0.05)$ as well as the Shannon indices of bacteria $(\mathrm{r}=0.484, P<0.05$, Table 5$)$. Tea yields were also significantly and positively correlated with contents of TN (r $=0.512, P<0.05)$, TP (r $=0.499, P<0.05)$, AN (r $=0.701, P<0.01)$, AP $(\mathrm{r}=0.679, P<0.01)$, and AK (r $=0.707, P<0.01$, Table 5) besides with SOM. So we know that, SOM contents increased with increasing levels

Table 5. Pearson correlation among microbial diversity indices, soil properties and tea yields.

\begin{tabular}{|c|c|c|c|c|c|c|c|c|c|c|c|}
\hline & $\mathrm{pH}$ & SOM & TN & $\mathrm{TP}$ & TK & $\mathrm{AN}$ & AP & AK & Tea yield & $H_{\mathrm{b}}^{\prime}$ & $H_{\mathrm{f}}^{\prime}$ \\
\hline $\mathrm{pH}$ & 1 & & & & & & & & & & \\
\hline SOM & 0.176 & 1 & & & & & & & & & \\
\hline $\mathrm{TN}$ & 0.158 & $0.987^{* *}$ & 1 & & & & & & & & \\
\hline $\mathrm{TP}$ & 0.053 & $0.964^{* *}$ & $0.966^{* *}$ & 1 & & & & & & & \\
\hline TK & -0.233 & -0.036 & 0.047 & 0.010 & 1 & & & & & & \\
\hline $\mathrm{AN}$ & 0.098 & $0.914^{* *}$ & $0.897^{* * *}$ & $0.900^{* *}$ & 0.001 & 1 & & & & & \\
\hline AP & -0.050 & $0.867^{* *}$ & $0.833^{* *}$ & $0.918^{* *}$ & -0.119 & $0.915^{* *}$ & 1 & & & & \\
\hline $\mathrm{AK}$ & 0.035 & $0.904^{* *}$ & $0.861^{* * *}$ & $0.896^{* *}$ & -0.168 & $0.923^{* *}$ & $0.924^{* *}$ & 1 & & & \\
\hline Tea yield & -0.086 & $0.589^{*}$ & $0.512^{*}$ & $0.499^{*}$ & -0.131 & $0.701^{* *}$ & $0.679^{* * *}$ & $0.707^{* *}$ & 1 & & \\
\hline$H_{\mathrm{b}}^{\prime}$ & $0.541^{*}$ & $0.484^{*}$ & 0.395 & 0.352 & -0.419 & 0.388 & 0.343 & 0.430 & 0.397 & 1 & \\
\hline$H_{\mathrm{f}}^{\prime}$ & 0.337 & -0.220 & -0.215 & -0.282 & -0.028 & -0.286 & -0.359 & -0.319 & -0.293 & 0.284 & 1 \\
\hline
\end{tabular}

${ }^{*} P=0.05 ;{ }^{* *} P=0.01$

SOM: Soil organic matter; TN: total N; TP: total P; TK: total K; AN: available N; AP: available P; AK: available K; $H_{\mathrm{b}}^{\prime}$ : Bacterial Shannon-Weaver index; $H_{\mathrm{f}}^{\prime}$ : fungal Shannon-Weaver index. 
of organic amendment, which in turn caused increases in TN, TP, AN, AP, AK contents in soils and soil bacterial diversity (Table 3). Subsequently, the improved soil in fertility provided more available nutrients for tea growth, and directly led to increase in tea yields. Therefore, organic amendment was a key factor in determining soil properties and productivity.

\section{CONCLUSIONS}

The results of the field experiment revealed that both $\mathrm{OM}$ and $1 / 2 \mathrm{NPKOM}+\mathrm{L}$ treatments showed much greater increase in tea yields, more effective improvement in soil chemical fertility, and higher diversity of bacterial community, compared to the other fertilizer treatments. Therefore, both OM and 1/2NPKOM+L treatments could be considered and recommended as better fertilization practices in tea soil in southeastern China.

\section{ACKNOWLEDGEMENTS}

This work was financially supported by the Special Fund (2010R1024-4) of fundamental scientific research at nonprofit research institutions in Fujian, the Natural Science Foundation (2011J05057) of Fujian Province, China and the Doctoral Research Fund (2010BS-7) of Fujian Academy of Agricultural Sciences, China.

\section{LITERATURE CITED}

Bassam, B.J., and G. Caetano-Anollés. 1993. Silver staining of DNA in polyacrylamide gels. Applied Biochemistry and Biotechnology 42:181-188.

Beauregard, M.S., C. Hamel, A. Atul-Nayyar, and M. St-Arnaud. 2010. Long-term phosphorus fertilization impacts soil fungal and bacterial diversity but not AM fungal community in alfalfa. Microbial Ecology 59:379-389.

Bremner, J.M. 1960. Determination of nitrogen in soil by the Kjeldahl method. Journal of Agricultural Science 55:11-33.

Carson, P.L. 1980. Recommended potassium test. p. 17-18. In Dahnke, W.C. (ed.) Recommended chemical soil test procedures for the North Central Region. Agricultural Experiment Station, Fargo, North Dakota, USA.

Costa, A.L., S.M. Paixão, I. Caçador, and M. Carolino. 2007. CLPP and EEA profiles of microbial communities in salt marsh sediments. Journal of Soils and Sediments 7:418-425.

Gu, Y.F., X.P. Zhang, S.H. Tu, and K. Lindström. 2009. Soil microbial biomass, crop yields, and bacterial community structure as affected by long-term fertilizer treatments under wheat-rice cropping. European Journal of Soil Biology 45:239-246.

Hai, L., X.G. Li, F.M. Li, D.R. Suo, and G. Guggenberger. 2010. Long-term fertilization and manuring effects on physicallyseparated soil organic matter pools under a wheat-wheat-maize cropping system in an arid region of China. Soil Biology and Biochemistry 42:253-259.

Hao, X.H., S.L. Liu, J.S. Wu, R.G. Hu, C.L. Tong, and Y.Y. Su. 2008 Effect of long-term application of inorganic fertilizer and organic amendments on soil organic matter and microbial biomass in three subtropical paddy soils. Nutrient Cycling in Agroecosystems $81: 17-24$
He, J.Z., Y. Zheng, C.R. Chen, Y.Q. He, and L.M. Zhang. 2008 Microbial composition and diversity of an upland red soil under long-term fertilization treatments as revealed by culturedependent and culture-independent approaches. Journal of Soils and Sediments 8:349-358.

Hu, J.L., X.G. Lin, J.H. Wang, J. Dai, R.R. Chen, J.B. Zhang, et al. 2011. Microbial functional diversity, metabolic quotient, and invertase activity of a sandy loam soil as affected by long-term application of organic amendment and mineral fertilizer. Journal of Soils and Sediments 11:271-280.

Jackson, M.L. 1958. Soil chemical analysis. p. 111-113. PrenticeHall, Englewood Cliffs, New Jersey, USA.

Kamaa, M., H. Mburu, E. Blanchart, L. Chibole, J.L. Chotte, C Kibunja, et al. 2011. Effects of organic and inorganic fertilization on soil bacterial and fungal microbial diversity in the Kabete longterm trial, Kenya. Biology and Fertility of Soils 47:315-321.

Kanchikerimath, M., and D. Singh. 2001. Soil organic matter and biological properties after 26 years of maize-wheat-cowpea cropping as affected by manure and fertilization in a Cambisol in semiarid region of India. Agriculture, Ecosystems and Environment 86:155-162.

Kennedy, A.C. 1999. Bacterial diversity in agroecosystems. Agriculture, Ecosystems and Environment 74:65-76.

Kumar, A., and D.S. Yadav. 2001. Long-term effects of fertilizers on the soil fertility and productivity of a rice-wheat system. Journal of Agronomy and Crop Science 186:47-54.

Larkin, R.P., C.W. Honeycutt, and T.S. Griffin. 2006. Effect of swine and dairy manure amendments on microbial communities in three soils as influenced by environmental conditions. Biology and Fertility of Soils 43:51-61.

Liu, E.K., C.R. Yan, X.R. Mei, W.Q. He, S.H. Bing, L.P. Ding, et al. 2010. Long-term effect of chemical fertilizer, straw, and manure on soil chemical and biological properties in northwest China. Geoderma 158:173-180.

Mäeder, P., A. Fließach, D. Dubois, L. Gunst, P. Fried, and U. Niggli. 2002. Soil fertility and biodiversity in organic farming. Science 296:1694-1697.

Murphy, J., and J.P. Riley. 1962. A modified single solution method for determination of phosphate in natural waters. Analytica Chimica Acta 27:31-36.

Muyzer, G., E.C. de Waal, and A.G. Uitterlinden. 1993. Profiling of complex microbial populations by denaturing gradient gel electrophoresis analysis of polymerase chain reaction-amplified genes coding for $16 \mathrm{~S}$ rRNA. Applied and Environmental Microbiology 59:695-700.

Naeem, S., and S. Li. 1997. Biodiversity enhances ecosystem reliability. Nature 390:507-509.

Peacock, A.D., M.D. Mullen, D.B. Ringelberg, D.D. Tyler, D.B. Hedrick, P.M. Gale, et al. 2001. Soil microbial community responses to dairy manure or ammonium nitrate applications. Soil Biology and Biochemistry 33:1011-1019.

Peng, X., X. Yan, H. Zhou, Y.Z. Zhang, and H. Sun. 2014. Assessing the contributions of sesquioxides and soil organic matter to aggregation in an Ultisol under long-term fertilization. Soil and Tillage Research http://dx.doi.org/10.1016/j.still.2014.04.003.

Powlson, D.S., A. Bhogal, B.J. Chambers, K. Coleman, A.J. Macdonald, K.W.T. Goulding, et al. 2012. The potential to increase soil carbon stocks through reduced tillage or organic material additions in England and Wales: a case study. Agriculture, Ecosystems and Environment 146:23-33.

Rousk, J., P.C. Brookes, and E. Bååth. 2009. Contrasting soil pH effects on fungal and bacterial growth suggests functional redundancy in carbon mineralisation. Applied and Environmental Microbiology 75:1589-1596.

Rousk, J., P.C. Brookes, and E. Bååth. 2010. Investigating the mechanisms for the opposing $\mathrm{pH}$ relationships of fungal and bacterial growth in soil. Soil Biology and Biochemistry 42:926934 
Shannon, C., and W. Weaver. 1963. The mathematical theory of communication. University of Illinois Press, Champaign, Illinois, USA.

Shen, J.P., L.M. Zhang, J.F. Guo, J.L. Ray, and J.Z. He 2010. Impact of long-term fertilization practices on the abundance and composition of soil bacterial communities in Northeast China. Applied Soil Ecology 46:119-124.

Šimek, M., D.W. Hopkins, J. Kalčík, T. Picek, H. Šantrůčková, J. Staňa, et al. 1999. Biological and chemical properties of arable soils affected by long-term organic and inorganic fertilizer applications. Biology and Fertility of Soils 29:300-308.

Sun, H.Y., S.P. Deng, and W.R. Raun. 2004. Bacterial community structure and diversity in a century-old manure-treated agroecosystem. Applied and Environmental Microbiology 70:5868-5874.

Thomas, G.W. 1996. Soil pH and soil acidity. p. 475-490. In Sparks, D.L. (ed.) Soil Science Society of America, Madison, Wisconsin, USA.

Vainio, E.J., and J. Hantula. 2000. Direct analysis of wood-inhabiting fungi using denaturing gradient gel electrophoresis of amplified ribosomal DNA. Mycological Research 104:927-936.

Venkatesan, S., S. Murugesan, M.N.K. Ganapathy, and D.P. Verma. 2004. Long-term impact of nitrogen and potassium fertilizers on yield, soil nutrients and biochemical parameters of tea. Journal of the Science of Food and Agriculture 84:1939-1944.
Walkley, A., and L.A. Black. 1934. An examination of the Degtjareff method of determining soil organic matter, and a proposed modification of the chromic acid titration method. Soil Science 37:29-38.

Weisburg, W.G., S.M. Barns, D.A. Pelletier, and D.J. Lane. 1991. 16 S ribosomal DNA amplification for phylogenetic study. Journal of Bacteriology 173:697-703.

Wu, M.N, H.L. Qin, Z. Chen, J.S. Wu, and W.X. Wei. 2011. Effect of long-term fertilization on bacterial composition in rice paddy soil. Biology and Fertility of Soils 47:397-405.

Yang, S.M., S.S. Malhi, F.M. Li, D.R. Suo, M.G. Xu, P. Wang, et al. 2007. Long-term effects of manure and fertilization on soil organic matter and quality parameters of a calcareous soil in NW China. Journal of Plant Nutrient and Soil Science 170:234-243.

Zhu, P., J. Ren, L.C. Wang, X.P. Zhang, X.M. Yang, and D. MacTavish. 2007. Long-term fertilization impacts on corn yields and soil organic matter on a clay-loam soil in Northeast China. Journal of Plant Nutrient and Soil Science 170:219-223. 